\title{
Transparency in the delivery of lawful abortion services
}

\author{
Rebecca J. Cook JD JSD
}

$\infty$ See related research paper by Bernabé-Ortiz and colleagues, page 298

I n this issue of CMAJ, Bernabé-Ortiz and colleagues report on their population-based survey that showed a high prevalence of induced abortions among women aged 18-29 in 20 cities in Peru. ${ }^{1}$ This study is important because official statistics on abortion are unavailable in Peru and access to abortion services is legally restricted. The authors' findings suggest that the government should move to prioritize the reproductive health needs of young women and women living in the jungle regions. Moreover, they show that the prevalence of abortion in Peru is as high as or higher than the prevalence in many countries where abortion services are legally available on extended grounds and are safe. This suggests that laws limiting access to abortion services do not reduce the number of abortions, only their safety.

Abortion is legal in Peru if it is required to save the life of the woman or to avoid serious, permanent damage to her physical or mental health. In practice, however, abortion is not generally available for these indications, owing in part to the barriers women face in gaining access to services. ${ }^{2}$ Abortions are therefore often undertaken in clandestine and unsafe conditions. As a result, rates of hospital admission because of complications are high. ${ }^{3}$

In 2005, the United Nations Human Rights Committee held the government of Peru to be in violation of the International Covenant on Civil and Political Rights for not providing a 17-year-old girl with an abortion to which she was legally entitled. ${ }^{4}$ The committee recommended that Peru provide the girl with an effective remedy, including compensation, and take steps to prevent the future occurrence of such violations. To date, the Peruvian government has not provided compensation, nor has it taken preventive steps. Such steps would include the issuing of a Ministry of Health guideline building on the standards established by the World Health Organization to ensure that abortion services are effectively available for the indications for which they are legal..$^{5}$ In addition, because Peru has ratified the Convention on the Elimination of All Forms of Discrimination Against Women, it is obligated to report periodically what it has done to bring its laws, policies and practices into compliance with this convention, including the collection of official statistics on abortion. Regrettably, the Peruvian government has failed to meet these international obligations.

In contrast, governments in other parts of Latin America and elsewhere are moving to ensure that terms and conditions under which legal abortion is permitted are made clear to women and health care providers. The government of Mexico conceded, in a friendly settlement of a dispute before the InterAmerican Commission on Human Rights, that it had violated the human rights of an adolescent rape victim by denying her access to abortion services to which she was lawfully entitled. ${ }^{6}$ In Colombia, the Constitutional Court awarded compensation against a government health care authority for its failure to

\section{Key points}

- Laws limiting access to abortion services do not reduce the number of abortions, only their safety.

- Governments of countries are obligated to collect official statistics on the number of abortions and their health effects.

- Where statistics show deficiencies in the delivery of abortion services, governments are obligated to remedy the problem.

- Governments are obligated to ensure that women, irrespective of age or other socio-demographic factors, have transparent access to abortion counselling and services where they are legal.

provide lawful abortion, aggravated by the failure of the legal system to protect an adolescent rape victim's human rights.? The Supreme Court of Justice of Bolivia issued an order to all judges in the lower courts to authorize abortions when they are legally indicated (i.e., to save the life or health of the woman and in cases of rape and incest). ${ }^{8}$ In Brazil, the combined efforts of the Brazilian Federation of Gynecology and Obstetrics Societies, women's health advocacy groups and the Brazilian Ministry of Health resulted in the issuing of guidelines that clarify how women can effectively access abortion services in cases of rape. ${ }^{9}$ In Uruguay, the Ministry of Public Health issued an ordinance that provides legal certainty for health care providers regarding the lawful status of abortion counselling and services. It also explains the officially required standard of care for the treatment of pregnant women. ${ }^{10}$

The treatment of women as full citizens with rights to equal protection under the law, including transparent access to legally entitled health services, is a universal legal principle to which governments outside of Latin America have also been made accountable. In Northern Ireland, the Court of Appeal held that the Department of Health, Social Services and Public Safety had failed to investigate whether women were receiving satisfactory abortion services and to provide guidance as to their local availability. ${ }^{11}$ As a consequence, health care providers were confused about the state of the law and fearful of liability to imprisonment, while women were denied access to abortion services to which they were lawfully entitled. The department has issued draft guidelines, ${ }^{12}$ but it has yet to adopt them. In Poland, the European Court of Human Rights held the government responsible for denying a woman a therapeutic abortion to which she was legally entitled. The denial caused her to become almost blind, which prevented her from working and severely inhibited her ability to care for herself and her children. ${ }^{13}$

Rebecca Cook is with the Faculty of Law, University of Toronto, Toronto, Ont.

All editorial matter in CMAJ represents the opinions of the authors and not necessarily those of the Canadian Medical Association. 
The implications of the decisions of the United Nations Human Rights Committee, the Constitutional Court of Colombia, the Northern Ireland Court of Appeal and the European Court of Human Rights are substantial. Where ministries of health fail to provide abortion services to women to which they are lawfully entitled and do not investigate whether women are actually receiving such services, ministries might be held legally liable for negligent violations of their local laws or international human rights. Where women do not have effective access to abortion services, failure to provide necessary guidance in order that they may receive services aggravates the violation.

When governments ignore evidence, such as that presented in the study by Bernabé-Ortiz and colleagues, and refuse to collect official statistics on abortion or ensure transparent access to legal abortion services, they are increasingly held accountable by national, regional and international human rights courts and tribunals for the arbitrary exercise of their power. They are also increasingly held accountable for causing preventable deaths and disabilities of women.

Competing interests: None declared.

\section{REFERENCES}

1. Bernabé-Ortiz A, White PJ, Carcamo CP, et al. Clandestine induced abortion: prevalence, incidence and risk factors among women in a Latin American country. CMAJ 2009;180:298-304.
2. My rights, and my rights to know - lack of access to therapeutic abortion in Peru. New York (NY): Human Rights Watch; 2008. Available: www.hrw.org/en/reports /2008/07/08/my-rights-and-my-right-know-0 (accessed 2008 Nov. 10).

3. Singh S. Hospital admissions resulting from unsafe abortion: estimates from $13 \mathrm{de}-$ veloping countries. Lancet 2006;368:1887-92.

4. Huamán v. Peru (2005), Communication no. 1153/2003, United Nations. Document no. CCPR/C/85/D/1153/2003 (Human Rights Commission).

5. World Health Organization. Safe abortion: technical and policy guidance for health systems. Geneva: The Organization; 2003. Available: www.who.int /reproductive-health/publications/safe_abortion/safe_abortion.pdf (accessed 2008 Nov. 10).

6. Paulina del Carmen Ramirez Jacinto v. Mexico (2007), Inter-Am. Comm. H.R. no. 21/07, Annual report of the Inter-American Commission on Human Rights. 2007-08, OEA/Ser.L./V/II.130/doc.22.

7. Decision T-209 of 2008 (Constitutional Court of Colombia).

8. Circular no. 25/08 from Eddy Walter Fernández Gutiérrez, President of the Supreme Court of Justice of Bolivia, to lower court judges; 2008 Oct. 17. Available: www.ipas.org/Library/News/News_Items/Bolivian_Supreme_Court_directs _courts_to_implement_abortion_policy.aspx (accessed 2008 Dec. 22).

9. Brazilian Ministry of Health. Prevention and treatment of harms resulting from sexual violence against women and adolescent girls. Brazilia (Brazil): The Ministry; 1999.

10. Ministerio de Salud Pública de la República Oriental del Uruguay. Asesoramiento para una maternidad segura. Medidas de protección frente al aborto provocado en condiciones de riesgo [Counselling for a safe motherhood. Preventive measures to avoid unsafe abortion]. Montevideo (Uruguay): The Ministry; August 2004.

11. Family Planning Association of Northern Ireland v. Minister for Health Social Services and Public Safety, [2005] N.I.L.R. 188 (C.A.).

12. Department of Health, Social Services and Public Safety, Northern Ireland. Guid ance on the termination of pregnancy in Northern Ireland [draft]. Belfast (UK): The Department; 2007. Available: www.dhsspsni.gov.uk/guidance-termination-of -pregnancy-NI-draft-Jan07.pdf (accessed 2008 Dec. 22).

13. Tysiac v. Poland (2007), Eur. Crt. H.R. 219.

Correspondence to: Dr. Rebecca J. Cook, Faculty of Law, University of Toronto, 84 Queen's Park, Toronto ON M5S 2C5; fax416 978-7899; rebecca.cook@utoronto.ca

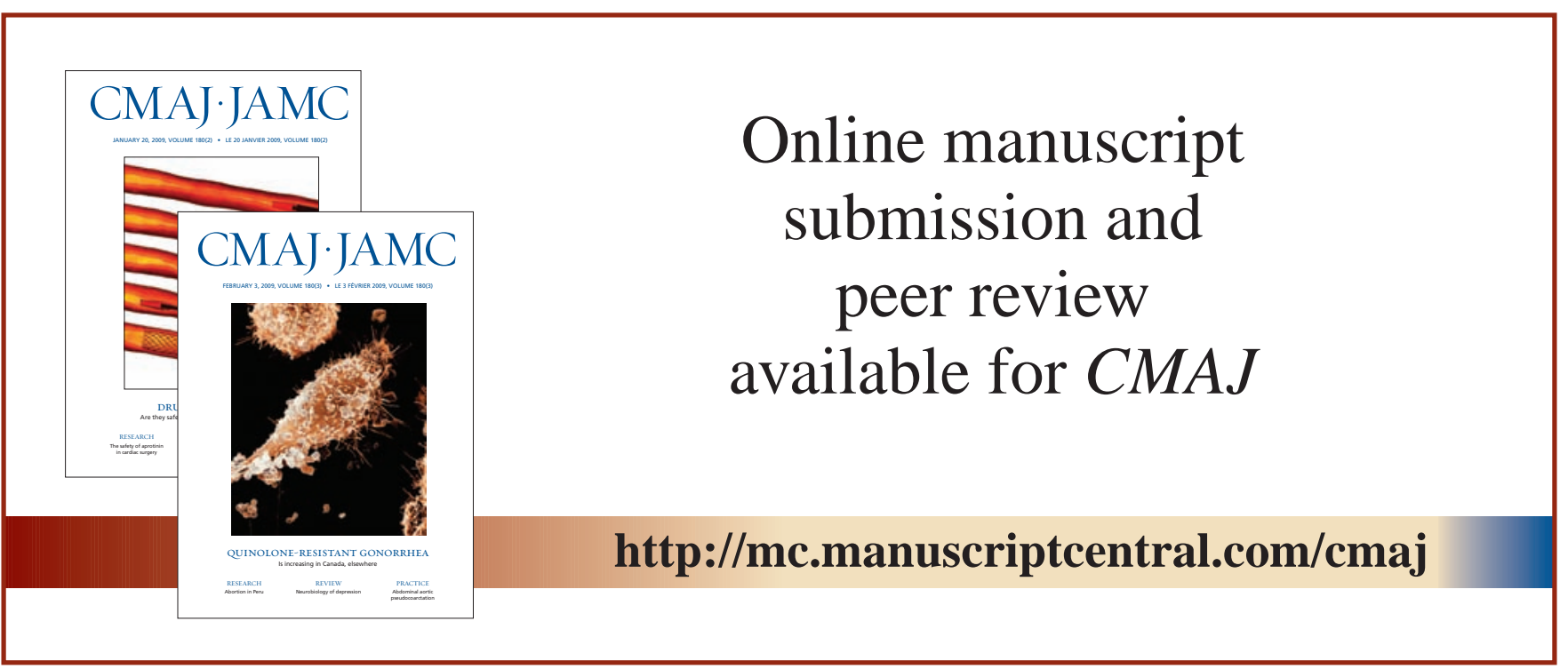

